\title{
LITERATURE REVIEW : HUBUNGAN TERAPI SENSORI INTEGRASI TERHADAP PERUBAHAN PERILAKU DAN KONSENTRASI ANAK ADHD (ATTENTION DEFICIT HYPERACTIVE DISORDER)
}

\section{Literature Review : Relationship Integrated Sensory Therapy To Changes In Behavior And Concentration Of Adhd Children (Attention Deficit Hyperactive Disorder)}

\section{Gabrina Watari \\ Austin Bertilova Carmelita $^{2}$}

Lia Sasmithae ${ }^{3}$

IPendidikan Dokter, Fakultas Kedokteran, Universitas

Palangka Raya, Palangka Raya, Kalimantan Tengah Indonesia

2Departemen Fisiologi, Fakultas

Kedokteran, Universitas

Palangka Raya, Palangka Raya,

Kalimantan Tengah Indonesia

3Departemen Ilmu Penyakit

Dalam, Fakultas Kedokteran,

Universitas Palangka Raya,

Palangka Raya, Kalimantan

Tengah Indonesia

*email:

rumentaliasulistini@gmail.com

\section{Kata Kunci:}

ADHD

Permainan

Musik

Menulis

Keywords:

ADHD

Games

Music

writing

\begin{abstract}
Abstrak
Attention deficit hyperactivity disorder (ADHD) merupakan kelainan neurobehavioral yang paling sering terjadi pada anak-anak merupakan suatu keadaan kronis berpengaruh pada anak-anak usia sekolah merupakan suatu gangguan mental. Salah satu terapi yang dapat digunakan adalah terapi sensori integrasi dengan bentuk terapi mengajak seorang anak untuk lebih mengembangkan kemampuan fisik yang dimilikinya. Penelusuran artikel ini untuk mengetahui hubungan terapi sensori integrasi terhadap perubahan perilaku dan konsentrasi anak ADHD (Attention Deficit Hyperactive Disorder). Penelusuran artikel melalui google schoolar,ditemukan sebanyak 18 jurnal yang akan di review. Ditemukan beberapa permainan yang mengatakan Terdapat hubungan terapi sensori integrasi terhadap perubahan perilaku dan konsentrasi anak ADHD, bermain jangka pendek meningkatkan konsentrasi anak, tebak isi gelas meningkatkan kosentrasi dan perilaku anak, permainan sosialisasi penurunan perilaku impulsif, bowling meningkatkan konsentrasi anak, game edukasi, playdough meingkatkan konsentrasi anak, PECS (Picture Exchange Communication System) meningkatkan kosentrasi anak, labirin meningkatkan kosentrasi, engklek meningkatkan kosentrasi anak, flashcard meningkatkan kosentrasi, musik meningkatkan kosentrasi dan menurunkan perilaku impulsif dan menulis meningkatkan kosentrasi dan menurunkan perilaku impulsif. Terdapat I jurnal yang menyatakan tidak berbeda antara kelompok terapi sensori integrasi dan kelompok yang tidak diterapi sensori integrasi. Terdapat hubungan terapi sensori integrasi terhadap perubahan perilaku dan konsentrasi anak ADHD Terapi sensori integrasi melibatkan kegiatan yang diyakini mengatur sistem sensorik dengan memberikan input vestibular, proprioseptif, auditori, dan sentuhan sehingga dapat mengurangi perilaku hiperaktif dan meningkatkan konsentrasi anak ADHD.
\end{abstract}

\begin{abstract}
Attention deficit hyperactivity disorder (ADHD), a neurobehavioral disorder that most often occurs in children, is a condition that affects school-age children as a mental disorder. One of the therapies that can be used is integrated sensory therapy with a form of therapy that encourages a child to develop their physical abilities. Search this article to see the relationship of integrated sensory therapy to changes in behavior and concentration of children with ADHD (Attention Deficit Hyperactive Disorder). Searching for articles through google schoolar, found 18 journals to be reviewed. There were several games that had a relationship between sensory therapy, integration of behavior changes and concentration of children with $A D H D$, short-term play increased children's concentration, guessing the contents of the glass increased children's concentration and behavior, socialization games decreased impulsive behavior, bowling increased children's concentration, game education, increased concentration play children, PECS (Picture Exchange Communication System) increases children's concentration, mazes increase concentration, cranks increase children's concentration, flashcards increase concentration, music increases concentration and decreases impulsive behavior and writing increases concentration and decreases impulsive behavior. There is I journal which states that there is no difference between the integrated sensory therapy group and the untreated sensory integration group. There is a relationship between integrated sensory therapy to behavior change and control of children with ADHD. Integration sensory therapy involves activities that manage the sensory system by providing vestibular, proprioceptive, auditory, and touch input so that it can reduce hyperactive behavior and increase constructive behavior in children with ADHD.
\end{abstract}




\section{PENDAHULUAN}

Attention deficit hyperactivity disorder (ADHD) merupakan kelainan neurobehavioral yang paling sering terjadi pada anak-anak merupakan suatu keadaan kronis yang paling sering berpengaruh pada anak-anak usia sekolah yang merupakan suatu gangguan mental.

Diperkirakan 9\% dari anak-anak antara usia 3-17 menderita $A D H D$ dan $4 \%$ orang dewasa menderita ADHD. Prevalensi ADHD pada anak usia sekolah di seluruh dunia dilaporkan sekitar 3-7\% dan di Amerika kasus ADHD dilaporkan sekitar 2-26\%. ADHD di Indonesia belum diketahui secara pasti. Gangguan ini sebesar 2,2\% untuk tipe hiperaktif-impulsif, serta 15,3\% untuk ADHD tipe inatensi. ADHD terjadi pada 3-5\% populasi anak dan didiagnosis $2-16 \%$ pada anak usia sekolah.

Para peneliti di National Institute of Mental Health $(\mathrm{NIMH})$, Institut Kesehatan Nasional $(\mathrm{NIH})$, dan di seluruh negeri mengatakan penyebab ADHD disebabkan oleh interaksi antara gen dan lingkungan atau faktor non-genetik. Seperti banyak penyakit lain, sejumlah faktor-faktor dapat berkontribusi pada ADHD seperti, gen, merokok, menggunakan alkohol, atau menggunakan narkoba selama kehamilan, paparan racun lingkungan pada usia muda berat badan lahir rendah cidera otak.

Terapi sensori integrasi merupakan bentuk terapi yang mengajak seorang anak untuk lebih mengembangkan kemampuan fisik yang dimilikinya. Salah satu cara yang efektif adalah bisa dengan menggunakan sebuah mainan, karena dengan bermain mereka akan lebih bersemangat dan terarah untuk lebih berkonsentasi dan memusatkan perhatiannya. Efektifnya terapi sensori integrasi menyebabkan timbulnya suatu kebutuhan akan sebuah rancangan produk yang dapat mengarahkan seorang anak penderita ADHD untuk lebih duduk diam serta memperhatikan sesuatu.

Penelitian yang dilakukan oleh Ruu-Fen Tzang et al 2018 menyebutkan bahwa tidak ada perbedaan yang signifikan antara kelompok sensori integrasi dan kelompok non
Sensori integrasi. Berbeda pada penelitian Deyla Erinta dan Meita Santi Budiani mengatakan bahwa penerapan terapi permainan sosialisasi efektif untuk menurunkan perilaku impulsif pada anak ADHD.

Berdasarkan uraian di atas, peneliti tertarik melakukan suatu literature review, untuk menegtahui hubungan terapi sensori integrasi terhadap perubahan perilaku dan konsentrasi anak ADHD (Attention Deficit Hyperactive Disorder).

\section{METODOLOGI}

Jenis penelitian Pada penelitian ini dilakukan pendekatan systematic literatur review yaitu sebuah literatur yang secara sistematik, jelas, menyeluruh dengan mengidentifikasi, mengevaluasi, dan mengumpulkan data-data penelitian yang sudah ada. Literature review ini berisi ulasan, rangkuman serta pemikiran bedasarkan sumber data hasil penelitian dari sumber pustaka. metode penggumpulan data atau sumber dari kepustakaan seperti, jurnal ilmiah.

Data yang akan digunakan dalam literature review ini berupa data sekunder. Sumber data sekunder dari penelitian-penelitian berupa jurnal dengan batas pencarian dari tahun 2010-2020. Sumber jurnal nasional pada penelitian ini diperoleh dari Google Cendekia, jurnal internasional diperoleh dari Google Scholar. Data sekunder diperoleh dari hasil penelitian yang telah dilakukan oleh peneliti sebelumnya berupa jurnal atau artikel publikasi yang menjelaskan hubungan terapi sensori integrasi terhadap perubahan perilaku dan konsentrasi anak ADHD (Attention Deficit Hyperactive Disorder). 
Pengumpulan literatur pada penelitian ini dijabarkan pada Gambar I sebagai berikut.

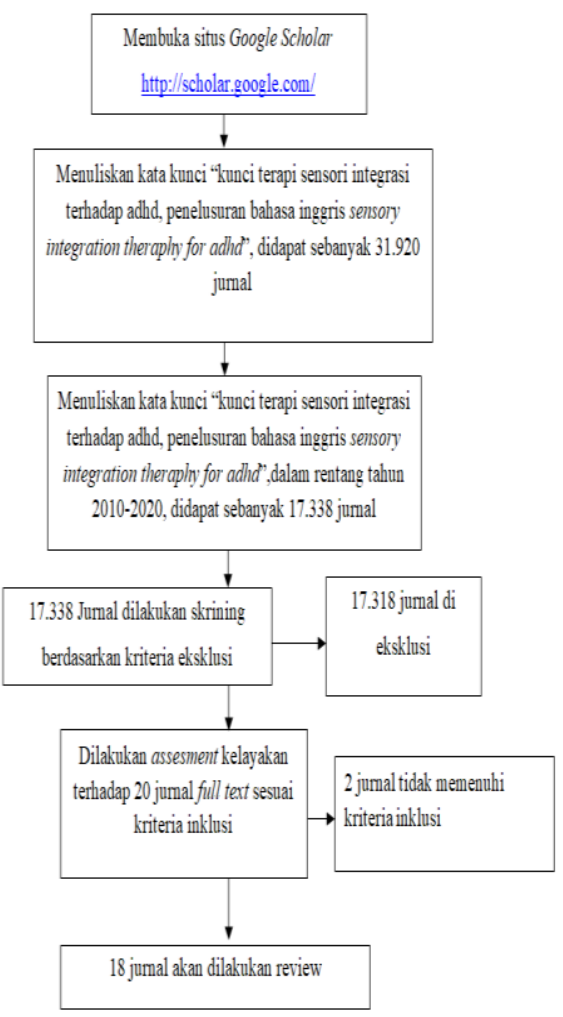

\section{HASIL DAN PEMBAHASAN}

Hasil sintesis data pada penelitian ini sebagai berikut.

Tabel I. Hasil Sintesis Data

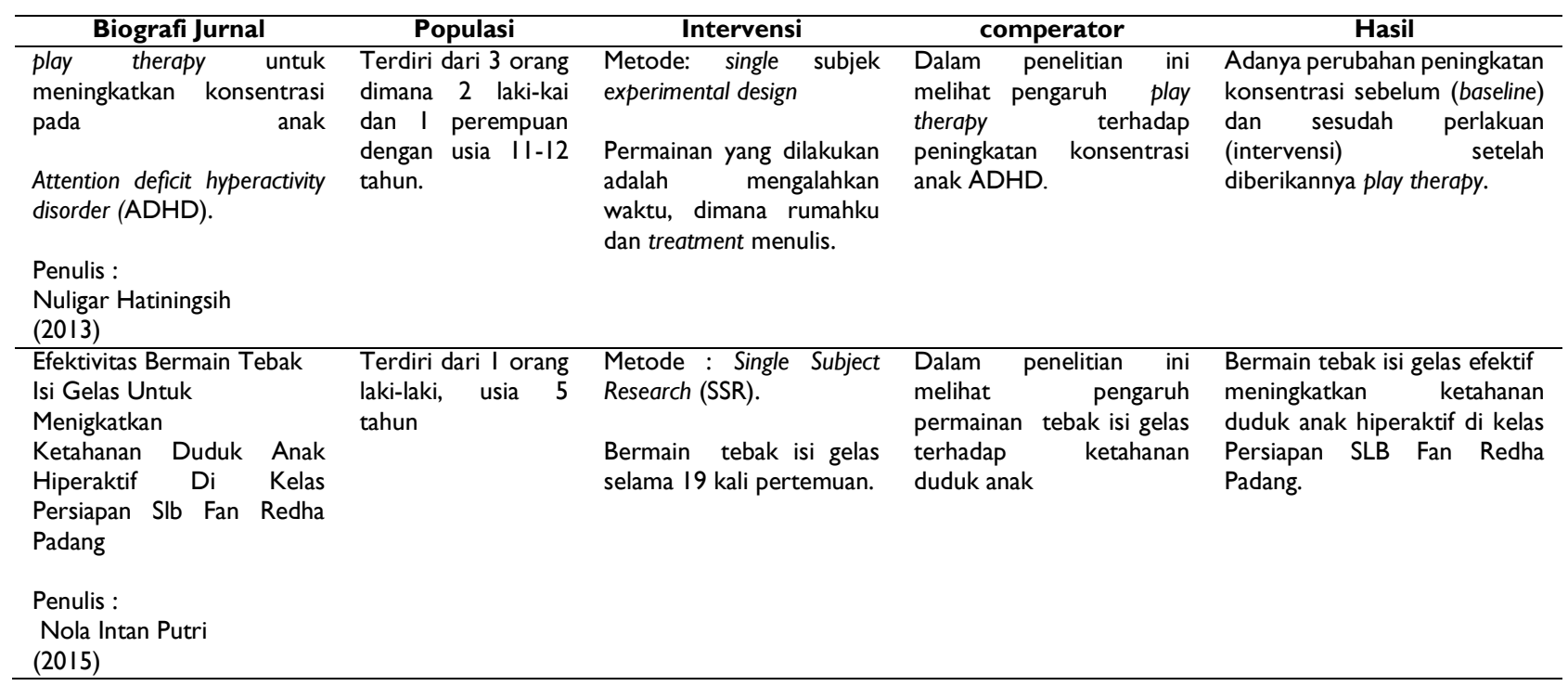




\begin{tabular}{|c|c|c|c|c|}
\hline $\begin{array}{l}\text { Efektivitas penerapan terapi } \\
\text { permainan sosialisasi untuk } \\
\text { menurunkan perilaku } \\
\text { impulsif pada anak dengan } \\
\text { Attention deficit hyperactivity } \\
\text { disorder (ADHD). } \\
\text { Penulis : } \\
\text { Deyla Erinta dan Meita Santi } \\
\text { Budiani } \\
(2012)\end{array}$ & $\begin{array}{l}\text { Terdiri dari } 5 \text { orang } \\
\text { dimana } 3 \text { laki-laki } \\
\text { dan } 2 \text { perempuan }\end{array}$ & $\begin{array}{l}\text { quasi } \\
\text { experiment } \\
\text { Permainan ayunan, } \\
\text { melempar bola, bermain } \\
\text { puzzle atau mainan } \\
\text { bongkar pasang, dan } \\
\text { estafet bola. }\end{array}$ & $\begin{array}{lr}\text { Dalam } & \text { penelitian ini } \\
\text { melihat } & \text { pengaruh } \\
\text { permainan } & \text { sosialisasi } \\
\text { terhadap } \quad \text { penurunan } \\
\text { perilaku impulsif pada anak } \\
\text { ADHD. }\end{array}$ & $\begin{array}{l}\text { Terapi permainan sosialisasi } \\
\text { efektif diberikan pada anak } \\
\text { dengan ADHD untuk } \\
\text { menurunkan perilaku impulsif } \\
\text { mereka. }\end{array}$ \\
\hline $\begin{array}{l}\text { Meningkatkan kemampuan } \\
\text { koordinasi gerak mata dan } \\
\text { tangan melalui } \\
\text { Permainan bowling adaptif } \\
\text { pada anak ADHD Attention } \\
\text { deficit hyperactivity disorder } \\
\text { Penulis : } \\
\text { M.Amirul Amin } \\
(2012)\end{array}$ & $\begin{array}{l}\text { Terdiri dari I orang } \\
\text { laki-laki }\end{array}$ & $\begin{array}{l}\text { Single Subject } \\
\text { Research } \\
\text { permainan bowling dengan } \\
\text { cara melempar bola, } \\
\text { mengambil bola, dan } \\
\text { menyusun benda }\end{array}$ & $\begin{array}{lr}\text { Dalam penelitian ini } \\
\text { melihat } \quad \text { pengaruh } \\
\text { Permainan bowling adaptif } \\
\text { terhdap peningkatan } \\
\text { konsentrasi koordinasi } \\
\text { gerak mata dan tangan. }\end{array}$ & $\begin{array}{l}\text { Berdasarkan hasil penelitian } \\
\text { terdapat } \\
\text { peningkatan konsentrasi yang } \\
\text { membuat kemampuan } \\
\text { koordinasi gerak mata dan } \\
\text { tangan pada anak ADHD } \\
\text { menjadi meningkat. }\end{array}$ \\
\hline $\begin{array}{l}\text { Pemanfaatan game edukasi } \\
\text { berbasis open source bagi } \\
\text { anak Attention deficit } \\
\text { hyperactivity disorder } \\
\text { (ADHD). } \\
\text { Penulis: } \\
\text { Detri Puspita Sari, } \\
\text { Muhammad Asrori, Usman } \\
\text { Radiana } \\
\text { (2016) }\end{array}$ & $\begin{array}{l}\text { Terdiri dari } 9 \text { orang } \\
\text { dimana } 5 \text { laki-laki } \\
\text {,dan } 4 \text { perempuan, } \\
\begin{array}{llr}\text { dengan usia } 5-8 \\
\text { tahun ) }\end{array}\end{array}$ & $\begin{array}{l}\text { Metode :quasi } \\
\text { experiment } \\
\text { Game Mengenal } \\
\text { Lingkunga, terdiri dari } \\
\text { mengenal warna, suara, } \\
\text { dan lain-lain. Game } \\
\text { Aktivitas Matematika, } \\
\text { mata uang, Game Aktivitas } \\
\text { Membaca, jenis game ini } \\
\text { mengenalkan huruf kepada } \\
\text { peserta didik } \\
\text { secara menyenangkan, } \\
\text { sehingga peserta didik } \\
\text { dapat belajar sambil } \\
\text { bermain. }\end{array}$ & $\begin{array}{l}\text { Dalam penelitian ini } \\
\text { melihat pengaruh game } \\
\text { edukasi terhadap respon } \\
\text { visual, respon audio dan } \\
\text { respon inisiatif. }\end{array}$ & $\begin{array}{l}\text { Peningkatan respon visual, } \\
\text { respon audio dan } \\
\text { respon inisiatif pada anak } \\
\text { ADHD (Attention Deficit } \\
\text { Hyperactivity Disorder) }\end{array}$ \\
\hline $\begin{array}{l}\text { Pengaruh bermain } \\
\text { playdough terhadap } \\
\text { kemampuan motorik halus } \\
\text { pada anak } \\
\text { ADHD. } \\
\text { Penulis : } \\
\text { Dhika Hariya Apriliantin, } \\
\text { Tri Peni, S.Kep.Ns.,M.Kes, } \\
\text { Siti Indatul Laili, S.Kep.Ns., } \\
\text { M.Kes } \\
(2019)\end{array}$ & $\begin{array}{l}\text { Terdiri drai } 20 \\
\text { orang dimana } 5 \text { laki- } \\
\text { laki dan I5 } \\
\text { perempuan, dengan } \\
\text { usia } 4-7 \text { tahun }\end{array}$ & $\begin{array}{l}\text { Metode : one group pretest- } \\
\text { post test design } \\
\text { Permain playdough dengan } \\
\text { cara menjumput, } \\
\text { mengelus, mencolek, } \\
\text { mengepal, memelintir, } \\
\text { memilin, dan memeras. }\end{array}$ & $\begin{array}{l}\text { Dalam penelitian ini } \\
\text { melihat pengaruh } \\
\text { playdough terhadap } \\
\text { motorik halus pada anak } \\
\text { ADHD. }\end{array}$ & $\begin{array}{l}\text { Playdough memberikan } \\
\text { dampak positif pada } \\
\text { kemampuan motorik halus } \\
\text { berupa menjumput, mengelus, } \\
\text { mencolek, mengepal, } \\
\text { memelintir, memilin, dan } \\
\text { memeras }\end{array}$ \\
\hline 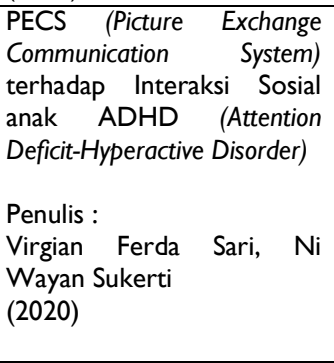 & Terdiri dari I orang & $\begin{array}{l}\text { Metode : Single Subject } \\
\text { Reseach } \\
\text { Penggunaan metode PECS } \\
\text { dilakukan melalui } 3 \text { tahap, } \\
\text { tahap pertama; cara anak } \\
\text { berkomunikasi. Tahap } \\
\text { kedua, Discrimination, } \\
\text { Tahap ketiga, responsive } \\
\text { requsting (menjawab } \\
\text { pertanyaan) }\end{array}$ & $\begin{array}{l}\text { Dalam penelitian ini } \\
\text { melihat pengaruh PECS } \\
\text { terhadap perubahan } \\
\text { perilaku anak ADHD. }\end{array}$ & $\begin{array}{l}\text { Pemberian intervensi (metode } \\
\text { PECS) terhadap perubahan } \\
\text { target perilaku (interaksi sosial } \\
\text { penolakan ajakan bermain anak } \\
\text { ADHD. }\end{array}$ \\
\hline $\begin{array}{l}\text { Permainan labirin dalam } \\
\text { meningkatkan konsentrasi } \\
\text { belajar anak ADHD } \\
\text { Penulis: } \\
\text { Intan Yolanda, Syaiful Bahri, } \\
\text { Fajriani } \\
(2018)\end{array}$ & Terdiri dari 3 orang & $\begin{array}{l}\text { Metode : single-subject } \\
\text { experimental design } \\
\text { Permainan labirin karena } \\
\text { merupakan salah satu } \\
\text { permainan edukatif yang } \\
\text { membutuhkan } \\
\text { konsentrasi, kesabaran } \\
\text { dan ketekunan anak dalam } \\
\text { melaluinya. }\end{array}$ & $\begin{array}{l}\text { Dalam penelitian ini } \\
\text { melihat pengaruh } \\
\text { permainan labirin terhadap } \\
\text { peningkatkan konsentrasi } \\
\text { belajar anak ADHD. }\end{array}$ & $\begin{array}{l}\text { Dari hasil penelitian diperoleh } \\
\text { adanya pengaruh posittif } \\
\text { penggunaan permainan labirin } \\
\text { pada anak yang mengalami } \\
\text { gangguan ADHD dengan } \\
\text { konsentrasi belajar rendah. }\end{array}$ \\
\hline
\end{tabular}




\begin{tabular}{|c|c|c|c|c|}
\hline $\begin{array}{l}\text { Pengaruh permainan } \\
\text { engklek terhadap motorik } \\
\text { kasar siswa ADHD kelas I } \\
\text { SDLB Wira Kusuma } \\
\text { Penulis : } \\
\text { Evi Tri Mulyani } \\
(2019)\end{array}$ & Terdiri dari I orang & 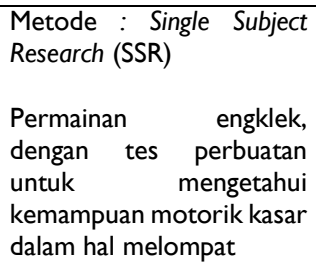 & $\begin{array}{lr}\text { Dalam } & \text { penelitian ini } \\
\text { melihat } & \text { pengaruh } \\
\text { permainan } & \text { engklek } \\
\text { terhadap } \quad \text { konsentrasi } \\
\text { untuk melompat. }\end{array}$ & $\begin{array}{lr}\text { Permainan } & \text { engklek } \\
\text { berpengaruh meningkatkan } & \text { monsentrasi untuk melompat. }\end{array}$ \\
\hline $\begin{array}{l}\text { Permainan flashcard untuk } \\
\text { Mengurangi perilaku } \\
\text { hiperaktif Siswa di SDN } \\
\text { INKLUSI } \\
\text { Penulis : } \\
\text { Sri Suwati Sujarwanto } \\
(2013)\end{array}$ & Terdiri dari I orang & $\begin{array}{l}\text { Metode : single subject } \\
\text { Desain } \\
\text { Permainan flashcard } \\
\text { bergambar buah, macam- } \\
\text { macam warna, benda dan } \\
\text { angka. }\end{array}$ & $\begin{array}{lr}\text { Dalam } & \text { penelitian ini } \\
\text { melihat } & \text { pengaruh } \\
\text { permainan } & \text { flashcard } \\
\text { terhadap } & \text { penurunan } \\
\text { perilaku hiperaktif anak } \\
\text { ADHD. }\end{array}$ & $\begin{array}{l}\text { Menunjukkan bahwa } \\
\text { permainan flascard dapat } \\
\text { mempengaruhi perilaku sering } \\
\text { berpindah tempat siswa di } \\
\text { SDN Inklusi Babatan V } \\
\text { Surabaya. }\end{array}$ \\
\hline $\begin{array}{l}\text { Increased risk of developing } \\
\text { psychiatric disorders in } \\
\text { children } \\
\text { with attention deficit and } \\
\text { hyperactivity disorder (ADHD) } \\
\text { receiving } \\
\text { sensory integration therapy: a } \\
\text { population-based cohort study } \\
\text { penulis : } \\
\text { Ruu-Fen Tzang, Yue-Cune } \\
\text { Chang, Kai-Liang Kao, } \\
\text { Yu-Hsin Huang, Hui-Chun } \\
\text { Huang,Yu-Chiao Wang, } \\
\text { Chih-Hsin Muo, Shu-I Wu, · } \\
\text { Fung-Chang Sung, · Robert } \\
\text { Stewart. } \\
\text { (20I8) }\end{array}$ & $\begin{array}{l}\text { Teridri dari } 1945 \\
\text { orang } \\
\text { dengan usia }<4 \\
\text { tahun } 227,>4 \\
\text { tahun } 1718\end{array}$ & $\begin{array}{l}\text { Metode : Cohort study } \\
\text { Perawatan SI termasuk } \\
\text { pelatihan koordinasi, } \\
\text { pelatihan sensorik, terapi } \\
\text { aktivitas, pelatihan } \\
\text { keseimbangan, pelatihan } \\
\text { ADL dan pelatihan } \\
\text { sensorik motorik. }\end{array}$ & $\begin{array}{l}\text { Membandingkan } \\
\text { kelompok yang di berikan } \\
\text { terapi sensori integrasi } \\
\text { dengan kelompok yang } \\
\text { tidak diberikan terapi } \\
\text { sensori inegrasi. }\end{array}$ & $\begin{array}{l}\text { Berdasarkan hasil penelitian } \\
\text { tidak terdapat perbedaan pada } \\
\text { perilaku antara kelompok } \\
\text { terapi sensori integrasi dan } \\
\text { kelompok yang tidak diterapi } \\
\text { sensori integrasi. }\end{array}$ \\
\hline $\begin{array}{l}\text { Ayres Sensory Integration for } \\
\text { the children with Attention } \\
\text { Deficit Hyperactivity Disorder } \\
\text { (ADHD): A Randomized } \\
\text { controlled trial } \\
\text { Penulis : } \\
\text { Hemant P Nandgaonkarand } \\
\text { Zarine D. Ferzandi. } \\
(2018)\end{array}$ & $\begin{array}{lll}\text { Terdiri } & \text { dari } & 96 \\
\text { orang } & & \end{array}$ & $\begin{array}{l}\text { Metode : This randomized } \\
\text { controlled trial } \\
\text { Permainan meja yang } \\
\text { menarik (misalnya, Seni } \\
\text { dan kerajinan, teka-teki, } \\
\text { balok, membaca cerita, } \\
\text { permainan interaktif) }\end{array}$ & $\begin{array}{l}\text { Dalam penelitian ini } \\
\text { melihat pengaruh } \\
\text { pemberian terapi sensori } \\
\text { integrasi terhadap }\end{array}$ & $\begin{array}{l}\text { Anak-anak di terapi sensori } \\
\text { integrasi memperoleh } \\
\text { perubahan pengorganisasian } \\
\text { masalah perilaku yang secara } \\
\text { signifikan lebih besar daripada } \\
\text { anak-anak di kelompok lain. }\end{array}$ \\
\hline $\begin{array}{l}\text { Effect of applying play } \\
\text { therapy on children with } \\
\text { attention deficit hyperactivity } \\
\text { disorder } \\
\text { Penulis : } \\
\text { Nahed Saied El-Nagger, } \\
\text { Manal Hassan Abo-Elmagd, } \\
\text { Hanan Ibrahim Ahmed } \\
(2017)\end{array}$ & $\begin{array}{l}\text { Teridri dari } 40 \\
\text { orang dengan usia } \\
4-12 \text { tahun }\end{array}$ & $\begin{array}{l}\text { Metode : quasi } \\
\text { experiment } \\
\text { Kegiatan seni, } \\
\text { cerita, mengajukan } \\
\text { pertanyaan, konstruksi } \\
\text { puzzle, permainan memori } \\
\text { kerja, permainan kursi dan } \\
\text { lagu }\end{array}$ & 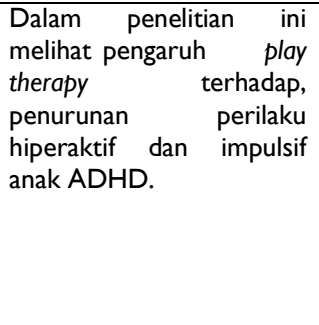 & $\begin{array}{l}\text { Terdapat } \text { perbedaan signifikan } \\
\text { terhadap, hiperaktif dan } \\
\text { impulsif anak sesudah } \\
\text { menerapkan terapi bermain. }\end{array}$ \\
\hline $\begin{array}{l}\text { The Influence of Educative } \\
\text { Puzzle Game to Concentration } \\
\text { of } \\
\text { Children with Attention Deficit } \\
\text { and Hyperactivity Disorder In } \\
\text { Arogya Mitra Acupuncture } \\
\text { Klaten }\end{array}$ & $\begin{array}{l}\text { Terdiri dari } 15 \\
\text { orang dengan usia } \\
6-12 \text { tahun }\end{array}$ & $\begin{array}{l}\text { Metode : pre-experimental } \\
\text { Permain puzzle selama } 5 \\
\text { hari berturut-turut selama } \\
\text { I5 menit }\end{array}$ & $\begin{array}{l}\text { Dalam penelitian ini } \\
\text { melihat pengaruh puzzle } \\
\text { terhadap konsentrasi anak } \\
\text { ADHD. }\end{array}$ & $\begin{array}{l}\text { Terdapat pengaruh permainan } \\
\text { puzzle edukatif } \\
\text { terhadap konsentrasi anak } \\
\text { dengan defisit perhatian dan } \\
\text { hiperaktif. }\end{array}$ \\
\hline $\begin{array}{l}\text { Penulis } \\
\text { Suyami, FN Khayati, } \\
\text { Setianingsih, C Pranandari } \\
(2019)\end{array}$ & & & & \\
\hline
\end{tabular}




\begin{tabular}{|c|c|c|c|c|}
\hline $\begin{array}{l}\text { The efficacy of short-term play } \\
\text { therapy for children in } \\
\text { reducing symptoms of ADHD } \\
\text { Penulis : } \\
\text { Marzie Hashemi, Shokooh } \\
\text { sadat Banijamali, Zohre } \\
\text { Khosravi } \\
(2018)\end{array}$ & $\begin{array}{l}\text { Terdiri dari } 6 \text { orang } \\
\text { dengan usia } 7-12 \\
\text { tahum }\end{array}$ & $\begin{array}{l}\text { Metode : Single subject } \\
\text { study } \\
\text { Terapi bermain } 30-50 \\
\text { menit selama } 10 \text { minggu }\end{array}$ & $\begin{array}{l}\text { Dalam penelitian ini } \\
\text { melihat pengaruh short- } \\
\text { term play therapy terhadap } \\
\text { penurunan gejala ADHD. }\end{array}$ & $\begin{array}{l}\text { Hasil penelitian menunjukkan } \\
\text { bahwa terapi bermain jangka } \\
\text { pendek efektif meningkatkan } \\
\text { perilku mereka. }\end{array}$ \\
\hline $\begin{array}{l}\begin{array}{l}\text { Program Intervensi } \\
\text { terhadap Musik } \\
\text { Hiperaktivitas }\end{array} \\
\begin{array}{l}\text { Anak Attention Deficit } \\
\text { Hyperactivity } \\
\text { (ADHD) }\end{array} \\
\text { Pisorder } \\
\text { Penulis: } \\
\text { Bestari Nindya Suyanto \& } \\
\text { Supra Wimbarti } \\
(2019)\end{array}$ & $\begin{array}{l}\text { Terdiri dari Iorang } \\
\text { laki-laki usia } 8 \text { tahun }\end{array}$ & $\begin{array}{l}\text { Metode : single case } \\
\text { experimental design } \\
\text { Musik merupakan sebuah } \\
\text { alunan yang dinamis dalam } \\
\text { bentuk instrumental } \\
\text { Heykens Serenade dan } \\
\text { Toseli Serenade yang } \\
\text { diperdengarkan kepada } \\
\text { anak selama } 30 \text { menit. }\end{array}$ & $\begin{array}{l}\text { Dalam penelitian ini } \\
\text { melihat pengaruh musik } \\
\text { terhadap penurunan } \\
\text { perilaku hiperaktivitas. }\end{array}$ & $\begin{array}{l}\text { Hasil penelitian menunjukkan } \\
\text { bahwa adanya penurunan } \\
\text { perilaku hiperaktif pada } \\
\text { partisipan RG setelah program } \\
\text { pemberian intervensi musik. }\end{array}$ \\
\hline $\begin{array}{l}\text { Pengaruh terapi musik dan } \\
\text { gerak terhadap penurunan } \\
\text { kesulitan berperilaku pada } \\
\text { siswa sekolah dasar dengan } \\
\text { gangguan ADHD } \\
\text { Penulis : } \\
\text { Diana Rusmawati, Endah } \\
\text { Kumala Dewi } \\
(20 \text { II) }\end{array}$ & $\begin{array}{l}\text { Terdiri dari I orang } \\
\text { laki-laki usia } 6-7 \\
\text { tahun }\end{array}$ & $\begin{array}{l}\text { Metode : Single Subject } \\
\text { Experimental Design } \\
\text { Penelitian ini menggunakan } \\
\text { permainan alat musik anak } \\
\text { berupa genderang kecil, } \\
\text { gitar kecil, organ kecil yang } \\
\text { berisi macam-macam } \\
\text { bunyi. }\end{array}$ & $\begin{array}{l}\text { Dalam penelitian ini } \\
\text { melihat pengaruh musik } \\
\text { terhadap penurunan } \\
\text { kesulitan berperilaku anak } \\
\text { ADHD. }\end{array}$ & $\begin{array}{l}\text { Hasil penelitian } \\
\text { pembahasan yang telah } \\
\text { dilakukan didapatkan bahwa } \\
\text { penerapan terapi musik dan } \\
\text { gerak dapat mereduksi } \\
\text { kesulitan berperilaku pada } \\
\text { siswa sekolah dasar yang } \\
\text { menderita ADHD. }\end{array}$ \\
\hline $\begin{array}{l}\text { Efektivitas terapi menulis } \\
\text { untuk } \\
\text { menurunkan hiperaktivitas } \\
\text { dan impulsivitas pada anak } \\
\text { dengan } \\
\text { ADHD(Attention Deficit } \\
\text { Hyperactivity Disorder). } \\
\text { Penulis: } \\
\text { Iffa Dwi Hikmawati, Erny } \\
\text { Hidayati } \\
\text { (20l4) }\end{array}$ & $\begin{array}{l}\text { Terdiri dari I orang } \\
\text { Laki-laki usia } 8 \\
\text { tahun }\end{array}$ & $\begin{array}{l}\text { Metode: single-case } \\
\text { experimental design } \\
\text { Pada fase perlakuan, } \\
\text { subjek diberikan perlakuan } \\
\text { berupa terapi menulis yang } \\
\text { berisi } \\
\text { tugas menebalkan dan } \\
\text { menulis huruf secara tegak } \\
\text { bersambung. }\end{array}$ & $\begin{array}{lr}\text { Dalam penelitian ini } \\
\text { melihat pengaruh terapi } \\
\text { menulis } & \text { terhadap } \\
\text { penurunan } & \text { perilaku } \\
\text { hiperaktivitas } & \text { dan } \\
\text { impulsivitas. } & \end{array}$ & $\begin{array}{l}\text { Terapi menulis dapat } \\
\text { menurunkan perilaku } \\
\text { hiperaktivitas dan impulsivitas } \\
\text { pada anak dengan ADHD } \\
\text { (Attention } \\
\text { Deficit Hiperactivity Disorder). }\end{array}$ \\
\hline $\begin{array}{l}\text { Permainan flashcard untuk } \\
\text { Mengurangi } \\
\text { hiperaktif Siswa di SDN } \\
\text { INKLUSI } \\
\text { Penulis: } \\
\text { Sri Suwati Sujarwanto } \\
(20 \mid 3)\end{array}$ & Terdiri dari I orang & $\begin{array}{l}\text { Metode : single subject } \\
\text { Desain } \\
\text { Permainan flashcard } \\
\text { bergambar buah, macam- } \\
\text { macam warna, benda dan } \\
\text { angka. }\end{array}$ & $\begin{array}{lr}\text { Dalam } & \text { penelitian ini } \\
\text { melihat } & \text { pengaruh } \\
\text { permainan } & \text { flashcard } \\
\text { terhadap } & \text { penurunan } \\
\text { perilaku hiperaktif anak } \\
\text { ADHD. }\end{array}$ & $\begin{array}{l}\text { Menunjukkan bahwa } \\
\text { permainan flascard dapat } \\
\text { mempengaruhi perilaku sering } \\
\text { berpindah tempat siswa di } \\
\text { SDN Inklusi Babatan V } \\
\text { Surabaya. }\end{array}$ \\
\hline
\end{tabular}

Literature yang di ambil untuk dilakukan review sebanyak I 8 jurnal, terdiri dari jurnal Indonesia sebanyak 13 jurnal yang menyatakan bahwa terapi sensori integrasi memberikan pengaruh terhadap perubahan perilaku dan konsentrasi anak ADHD dan jurnal internasional sebanyak 4 jurnal mengatakan bahwa terapi sensori integrasi memberikan pengaruh terhadap perubahan perilaku dan konsentrasi anak ADHD. Sedangkan I jurnal mengatakan bahwa tidak ada pengaruh terhadap perubahan perilaku dan konsentrasi anak ADHD.

Metode yang digunakan 17 jurnal yang menyatakan bahwa mengatakan bahwa terapi sensori integrasi berhubungan terhadap perubahan perilaku dan konsentrasi anak ADHD yaitu, single subjek experimental design, quasi experiment, one group pretest-post test design, This randomized controlled trial. Metode yang digunakan oleh I jurnal yang menyatakan bahwa tidak ada hubungan terapi sensori integrasi pengaruh terhadap perubahan perilaku dan konsentrasi anak ADHD yaitu Cohort study. Terdapat I penelitian yang dilakukan oleh Ruu-Fen Tzang et.al mengatakan bahwa terapi sensori integrasi tidak berhubungan terhadap perubahan perilaku dan konsentrasi anak ADHD. Penelitian ini mengelompokkan Subjek yang menerima perawatan 
Sensori intgerasi dan yang tidak menerima perawatan. Antara yang menerima sensori integrasi terutama yang mengalami gangguan perilaku pada ADHD tidak berbeda antara kelompok terapi sensori integrasi dan kelompok yang tidak diterapi sensori integrasi.

Berdasarkan 17 jurnal yang menyatakan terdapat hubungan antara terapi sensori integrasi terhadap perubahan perilaku dan konsentrasi anak ADHD, terdapat I jurnal membahas terapi sensori integrasi secara umum, sesuai penelitian dilakukan oleh Hemant P Nandgaonkarand. Menyimpulkan bahwa Anak-anak di terapi sensori integrasi memperoleh perubahan yang secara signifikan lebih besar daripada anak-anak di kelompok lain, selain itu terdapat 13 jurnal terapi permainan, 2 jurnal terapi musik, dan I jurnal terapi menulis. Terdapat beberapa permainan yang diterapkan dalam terapi sensori integrasi yaitu, play theraphy, bermain jangka pendek, tebak isi gelas, permainan sosialisasi, bowling, game edukasi, playdough, PECS (Picture Exchange Communication System), labirin, engklek, flashcard, musik dan menulis.

Play theraphy adalah salah satu alat untuk membangun komunikasi bagi anak-anak bermasalah dengan perilaku, dimana dengan bermain membantu dalam meningkatkan konsentrasi. Terdapat 2 jurnal yang membahas pengaruh tersebut yang diteliti oleh Jurnal ini diteliti oleh Nuligar Hatiningsih, serta Nahed Saied El-Nagger. Peneliti menyimpulkan Play therapy sangat membantu anak untuk meningkatkan konsentrasi karena dalam permainan anak belajar untuk melatih perkembangan motorik, sensori, kognitif dan konsentrasi.

Terapi bermain jangka pendek adalah kombinasi dari berbagai strategi klinis yang diuji dengan pendekatan multi-dimensi yang digunakan untuk anak-anak ADHD untuk membantu merawat mereka dengan lebih efisien. Jurnal ini diteliti oleh Marzie Hashemi et.al berdasarkan hasil penelitian efektivitas terapi bermain jangka pendek untuk anak-anak dalam mengurangi gejala ADHD yang diukur setiap minggu dengan Conners Parent
Questionnaire didapatkan terapi bermain jangka pendek efektif untuk menurunkan gejala ADHD.

Bermain tebak isi gelas dapat meningkatkan daya konsentrasi, mengurangi perilaku hiperaktif, warna dapat berperan penting dalam mendinginkan atau menenangkan otak anak hiperaktif dan reinforcement atau imbalan dapat mempertahankan atau memperkuat perilaku yang diharapkan. Terdapat I jurnal yang membahas pengaruh tersebut yang diteliti oleh Nola Intan Putri. Berdasarkan hasil penelitian yang dilakukan pada hasil intervensi frekuensi meninggalakan tempat duduk anak terus menurun melalui bermain tebak isi gelas terus menurun secara bertahap, anak mampu memusatkan perhatian secara penuh. Salah satu cara untuk memberikan pembelajaran yang menyenangkan bagi anak adalah dengan cara bermain tebak isi gelas. Terapi permainan sosialisasi merupakan suatu upaya yang dapat menghantarkan anak yang bersangkutan melalui permainan tertentu agar mampu menguasai keterampilan baru yang kemudian dikembangkan menjadi keterampilan khusus. ada 5 jenis permainan sosialisasi yaitu ayunan, melempar bola, bermain puzzle atau mainan bongkar pasang, dan estafet bola. Terdapat 2 jurnal yang membahas pegaruh tersebut yang diteliti oleh Deyla Erinta dan Meita Santi Budiani, serta Menurut Suyami et.al. Berdasarkan hasil penelitian terjadi penurunan perilaku impulsif setelah diberikan terapi permainan sosialisasi hingga menunjukkan penurunan perilaku impulsif yang stabil pada saat diberikan post-test dan permainan konstruktif seperti puzzle juga akan membantu anak mengenal urutan, membantu mengembangkan motorik, dan mengembangkan kognitif.

Bowling adalah cabang olah raga yang berupa permainan dengan menggelindingkan bola khusus untuk merobohkan sejumlah gada/pin yang berderet, kemudian dapat tertata secara otomatis. Terdapat I jurnal yang membahas pengaruh tersebut yang diteliti oleh M. Amirul Amin. berdasarkan hasil penelitian, pada kondisi intervensi terjadinya peningkatan kemampuan 
koordinasi mata dan tangan anak, anak mampu melakukan satu sampai enam tes perbuatan yang diberikan hingga pertemuan terakhir.

Game edukasi yaitu suatu kegiatan yang sangat menyenangkan dan dapat digunakan sebagai cara atau alat pendidikan yang bersifat mendidik. Terdapat I jurnal yang membahas pengaruh tersebut yang diteliti oleh Detri Puspita Sari et.al. Berdasakan hasil observasi selama 3 minggu penggunaan game edukasi berbasis open source, terdapat beberapa kecenderungan perilaku yang lebih baik sebagai reaksi terhadap aktivitas bermain game edukasi berbasis open sources ehingga meningkatkan respon visual, respon audio, dan respon inisiatif.

Playdough adalah adonan mainan yang merupakan bentuk modern dari clay atau lempung yang terbuat dari campuran tepung terigu. Terdapat I jurnal yang membahas pengaruh tersebut yang diteliti oleh Dhika Hariya Apriliantin et.al. Berdasarkan hasil penelitian Menunjukkan bahwa hampir setengah responden mempunyai kemampuan motorik halus cukup sebelum bermain playdough terjadi peningkatan kemampuan motorik halus berupa menjumput, mengelus, mencolek, mengepal, memelintir, memilin, dan memeras yang signifikan sesudah bermain playdough.

PECS adalah alternatif sistem komunikasi yang digunakan untuk mengajarkan komunikasi secara fungsional kepada anak. Terdapat I jurnal yang membahas pengaruh tersebut yang diteliti oleh Virgian Ferda Sari dan Ni Wayan Sukerti. Berdasarkan hasil analisis data menunjukan frekuensi anak dalam penolakan ajakan bermain berada pada kisaran 2 kali penolakan pada sesi intervensi setelah diberi beberapa kali perlakuan dengan metode PECS mengalami penurunan frekuensi penolakan ajakan bermain anak ADHD, membuat anak mengolah informasi secara langsung dengan tindakan yang dimunculkan sesuai gambar.

Permainan labirin merupakan salah satu permainan edukatif yang membutuhkan konsentrasi, kesabaran dan ketekunan anak. Terdapat I jurnal yang membahas pengaruh tersebut yang diteliti oleh Intan Yolanda et.al. Berdasarkan hasil analisis data hasil analisis terdapat perubahan level dalam kondisi dengan level peningkatan pada fase intervensi. Bermain labirin, lambat laun mental anak akan terbiasa untuk bersifat tenang, berkonsentrasi, dan sabar dalam menyelesaikan sesuatu. Bermain engklek merupakan kegiatan yang menyenangkan dan menarik bagi anak-anak. Terdapat I jurnal yang membahas pengaruh tersebut yang diteliti oleh Evi Tri Mulyani. Berdasarkan hasil penelitian permainan engklek berpengaruh terhadap motorik kasar, hal ini terlihat dari selisih level perubahan dari fase baseline (A) sampai awal fase intervensi (B) yang meningkat.

Permainan flashcard adalah permainan yang menggunakan kartu flashcard adalah permainan dengan menggunakan kartu sebagai medianya yang bertujuan untuk membantu siswa hiperaktif mengurangi perilakunya yang kurang kondusif. Terdapat I jurnal yang membahas pengaruh tersebut yang diteliti oleh Sri Suwati dan Sujarwanto. Berdasarkan hasil penelitian dapat dilihat berkurangnya perilaku hiperaktif sering pindah tempat melalui permainan flashcard dimana siswa diajak bermain secara terus menerus sampai siswa mampu mengurangi perilaku sering pindah tempat. Flashcard mengekspresikan dan mengkomunikasikan tentang gambar apa yang telah dilihat dan apa yang tertulis dibawahnya sehingga dapat mengurangi perilaku hiperaktif.

Terapi musik merupakan salah satu jenis terapi yang dapat digunakan untuk mental illness. Terdapat 2 jurnal yang membahas pengaruh tersebut yang diteliti oleh Bestari Nindya Suyanto dan Supra Wimbarti, serta Diana Rusmawati dan Endah Kumala Dewi menyebutkan bahwa musik dapat memberikan pengaruh terhadap penurunan perilaku hiperaktivitas. Berdasarkan hasil penelitian adanya penurunan, mengindikasikan jika intervensi musik ini dapat menurunkan perilaku hiperaktif pada subjek. Ketika 
seseorang mendengarkan musik, otak memproses musik tersebut di dalam auditory cortex melalui thalamus yang memiliki fungsi untuk memusatkan perhatian pada stimulus sensorik tertentu.

Terapi menulis suatu bentuk perlakuan melalui media menulis yang membutuhkan kemampuan gerak lengan, jari dan mata secara terintegrasi. Terdapat I jurnal yang membahas pengaruh tersebut yang diteliti oleh Iffa Dwi Hikmawati et.al. menyebutkan bahwa Terapi menulis dapat menurunkan perilaku hiperaktivitas dan impulsivitas pada anak dengan ADHD (Attention Deficit Hiperactivity Disorder). Pada saat menulis akan terjadi peningkatan aktivitas pada susunan saraf pusat dan bagian- bagian organ tubuh Saraf-saraf spinal tersebut selanjutnya meneruskan rangsangan motorik melalui piramidal dari otak untuk selanjutnya berhubungan dengan sum-sum tulang belakang yang berfungsi untuk mengaktifkan otot-otot lengan, tangan, dan jari-jari untuk menulis sebagai respon rangsangan yang diterima.

\section{KESIMPULAN}

Literature review ini bertujuan untuk mengetahui hubungan terapi sensori integrasi terhadap perubahan perilaku dan konsentrasi anak ADHD (Attention Deficit Hyperactive Disorder) penelitian antara tahun 2010-2020, diperoleh 18 jurnal yang terdiri dari 13 jurnal Indonesia dan 5 jurnal internasional. Peneliti yang menyatakan terdapat hubungan terapi sensori integrasi terhadap perubahan perilaku dan konsentrasi anak ADHD (Attention Deficit Hyperactive Disorder) sebanyak 17 jurnal, sedangkan yang mengatakan tidak ada hubungan sebanyak I jurnal. Jurnal yang menyatakan berpengaruh ada beberapa menggunakan metode diantaranya, single subjek experimental design dimana penelitian menggunkan teknik pengumpulan data yang digunakan yaitu dengan menggunakan observasi secara langsung yang dilakukan untuk mencatat durasi konsentrasi subjek pada saat kejadian atau perilaku. Observasi dilakukan pada saat pretest (fase baseline A) dan selama pemberian treatment (fase intervensi B). Quasiexperimental dengan jenis time series design, alasan menggunakan metode time series design adalah karena subjek. merupakan kelompok anak yang mengalami ADHD penelitian yang digunakan pada anak ADHD dilakukan melalui observasi pre-test dan post-test. Randomized controlled trial (RCT), dimana populasi yang menerima intervensi dipilih secara acak dari populasi yang memenuhi syarat. Jurnal yang menyatakan tidak berpengaruh menggunakan metode cohot study merupakan studi observasional yang melihat hubungan paparan dan penyakit, pada penelitian membandingkan kelompok yang diberi terapi dan yang tidak diberi terapi sensori integrasi. Hasil penelitian yang sudah pernah dilakukan memperlihatkan lebih banyak jurnal yang menyatakan ada hubungan terapi sensori integrasi terhadap perubahan perilaku dan konsentrasi anak ADHD sehingga dapat membuktikan bahwa hubungan terapi sensori integrasi terhadap perubahan perilaku dan konsentrasi anak ADHD (Attention Deficit Hyperactive Disorder) merupakan bukti ilmiah yang kuat. Terapi sensori integrasi melibatkan kegiatan yang diyakini mengatur sistem sensorik dengan memberikan input vestibular, proprioseptif, auditori, dan sentuhan sehingga dapat mengurangi perilaku hiperaktif dan meningkatkan konsentrasi anak ADHD.

\section{UCAPAN TERIMA KASIH}

Ucapan terima kasih kepada Fakultas Kedokteran Universitas Palangka Raya yang memberikan fasilitas dan prasarana untuk saya menempuh program studi pendidikan dokter dan akhirnya saya bisa menyelesiakan literature review ini, kepada kedua pembimbing saya $\mathrm{dr}$. Austin Bertilova Carmelita, M.Imun dan dr. Lia Sasmithae, Sp.PD yang telah memberikan bimbingan serta ilmu kepada saya sehingga bisa menyelesiakan literature review ini. 


\section{REFERENSI}

I. Tzang R. F., Chang Y. C., Kao K. L., Huang Y. H., Huang H. C., Wang Y. C., Stewart R. 2018. Increased risk of developing psychiatric disorders in children with attention deficit and hyperactivity disorder (ADHD) receiving sensory integration therapy: a population-based cohort study. European child \& adolescent psychiatry. 28(2):247-255

2. Hatiningsih N. 2013. Play therapy untuk meningkatkan konsentrasi pada anak attention deficit hyperactive disorder (ADHD). Jurnal ilmiah psikologi terapan. I(2):324-342

3. Putri N. I. 2017. Efektivitas bermain tebak isi gelas untuk meningkatkan ketahanan duduk anak hiperaktif di kelas persiapan SLB fan redha padang (Single Subject Research). lurnal Penelitian Pendidikan Khusus [Internet\}. 4(3) Available from : http://ejournal.unp.ac.id/index.php/jupekhu/article/ view/7065/5563

4. Erinta D., Budiani M. S. 2012. Efektivitas penerapan terapi permainan sosialisasi untuk menurunkan perilaku impulsif pada anak dengan attention deficit hyperactive disorder (ADHD). Jurnal Psikol Teori dan Terapi. 3(I): 67-78.

5. Sari D. P., Asrori M., Radiana, U. 2016. Pemanfaatan game edukasi berbasis open source bagi anak attention deficit hyperactivity disorder (adhd) (Doctoral dissertation, Tanjungpura University) [Internet]. Available from : https://media.neliti.com/media/publications/214934 -pemanfaatan-game-edukasi-berbasis-open-s.pdf

6. Amin A. 20I2. Meningkatkan kemampuan koordinasi gerak mata dan tangan melalui permainan bowling adaptif pada anak adhd attention deficit hyperactive disorder. Jurnal IImiah Pendidikan Khusus. I(02).

7. Rusmawati D., Kumala Dewi E. 20II. Pengaruh Terapi Musik dan Gerak Terhadap Penurunan kesulitan Perilaku Siswa Sekolah Dasar Dengan Gangguan ADHD. Jurnal Psikologi Universitas Diponegoro 「Internet]. 9(I). Available from : https://ejournal.undip.ac.id/index.php/psikologi/arti cle/view/29/3/2597

8. Apriliantina D. H., Peni T., Laili, S. I. 2019. Pengaruh bermain playdough terhadap kemampuan motorik halus pada anak attention deficit/ hyperactivity.

9. Sari V. F., Ni Wayan S. 2020. PECS (Picture Exchange Communication System) terhadap Interaksi Sosial anak ADHD (Attention Deficit-Hyperactive Disorder) [Internet]. Available from https://journal.uny.ac.id/index.php/jpk/article/view/307 97/Virgian\%20Ferda\%20Sari

10. Yolanda I., Bahri S., Fajriani, F. 2019. Penerapan permainan labirin untuk konsentrasi pada anak ADHD (attention deficit hyperactivity disorder) di SLB BUKESRA BANDA ACEH. JIMBK: Jurnal Ilmiah Mahasiswa Bimbingan \& Konseling. 4(3).

II. Mulyani E. T. 2019. Pengaruh permainan engklek terhadap motorik kasar siswa ADHD kelas I SDLB Wira Kusuma Journal of Special Education. 2(2):4958.

12. Suwati S. 20I3. Permainan flashcard untuk Mengurangi perilaku hiperaktif Siswa di SDN INKLUSI. Jurnal Pendidikan Khusus. 2(2).

13. Nandgaonkar H. P., Ferzandi Z. D. 2018. Ayres Sensory Integration for the children with Attention Deficit Hyperactivity Disorder (ADHD): A Randomized controlled trial. Int. J. Adv. Res [Internet], 6(I0): 103 II2. Available from: http://www.journalijar.com/uploads/230_JAR$\underline{25150 . p d f}$

14. El-Nagger N. S., Abo-Elmagd M. H., Ahmed H. I. 2017. Effect of applying play therapy on children with attention deficit hyperactivity disorder. Jurnal Nurs Educ Pract. 7(5): 104.

I5. Khayati F. N., Pranandari C. 2019. The Influence of Educative Puzzle Game to Concentration of Children with Attention Deficit and Hyperactivity Disorder In Arogya Mitra Acupuncture Klaten. In Journal of Physics: Conference Series [Internet]. Available from https://iopscience.iop.org/article//0.1088/I7426596/1179/1/012129/pdf

16. Hashemi M., Banijamali S. S., Khosravi, Z. 20I8. The efficacy of short-term play therapy for children in reducing symptoms of ADHD. World Family Medicine Journal Incorporating the Middle East / of Family Medicine [Internet]. Available from : https://platform.almanhal.com/Files/Articles/I I746 $\underline{6}$

17. Suyanto B. N., Wimbarti, S. 2019. Program Intervensi Musik terhadap Hiperaktivitas Anak Attention Deficit Hyperactivity Disorder (ADHD). Gadjah Mada lournal of Professional Psychology (GamaJPP) [Internet]. 5(I). Available from: https://journal.ugm.ac.id/gamajpp/article/view/4858 $\underline{4 / 25 \mid 45}$ 
18. Hikmawati I. D., Hidayati, E. 2014. Efektivitas Terapi Menulis untuk Menurunkan Hiperaktivitas dan Impulsivitas pada Anak dengan Attention Deficit Hyperactivity Disorder (ADHD). Empathy [Internet]. 2(I). Available from https://media.neliti.com/media/publications/241542 -efektivitas-terapi-menulis-untuk-menurune5ddf082.pdf

19. Hadiati T. 2018. Hubungan antara pola menyusui lbu dengan gangguan ADHD pada anak. Jurnal Nutr Heal. 6(1): 17-20.

20. Susanto B., Sengkey L. 2016. Diagnosis dan penanganan rehabilitasi medik pada anak dengan Attention Deficit Hyperactivity Disorder. Jurnal Biomedik. 8(3): I57-66.

21. Loedolff S. Attention deficit hyperactivity disorder: towards an inclusive approach in the management of ADHD in South African classrooms. 2019. University Of Cape Town [Internet]. Available From:https://open.uct.ac.za/bitstream/handle/I | 42 $7 / 31466 /$ thesis hum 2019 loedolff simone.pdf? is Allowed $=y \&$ sequence $=1$

22. McClenney-Rosenstein L. Sensory Integration: Exploring the Benefits for Students with Autism at the Secondary Level. Northeastern University, Aberdeen.[Internet]. 2019. Available from: https://search.proquest.com/openview/a6bafeb991 dd35998b6daab6e607/3ad/I?pqorigsite $=$ gscholar $\& \mathrm{cbl}=\mid 8750 \&$ diss $=y$ 